\title{
Chemical contents and medical importance of Dianthus caryophyllus- A review
}

\author{
Prof Dr Ali Esmail Al-Snafi \\ Department of Pharmacology, College of Medicine, Thi qar University, Iraq:
}

\begin{abstract}
Phytochemical analysis of Dianthus caryophyllus showed that it contained triterpenes, alkaloids, coumaruns, cyanogenic glycoside, cyanidin, pelargonidin, the yellow isosalipurposide, essential oil, volatile oil and many other chemical contents. Pharmacological studies revealed that the plant possessed anticancer, antiviral, antibacterial, antifungal, insecticidal, repellent, antioxidant, reno-protective, anesthetic and analgesic effects. The current review highlights the chemical constituents and pharmacological effects of Dianthus caryophyllus.
\end{abstract}

Keywords: chemical constituents, pharmacology, Dianthus caryophyllus

\section{INTRODUCTION:}

A large and increasing number of patients in the world use medicinal plants and herbs for health purpose. Therefore, scientific scrutiny of their therapeutic potential, biological properties, and safety will be useful in making wise decisions about their use. Recent reviews showed that plants produce many secondary metabolites which are bio-synthetically derived from primary metabolites and constitute an important source of many drugs [1-60]. Phytochemical analysis of Dianthus caryophyllus showed that it contained triterpenes, alkaloids, coumaruns, cyanogenic glycoside, cyanidin, pelargonidin, the yellow isosalipurposide, essential oil, volatile oil and many other chemical contents. Pharmacological studies revealed that the plant possessed anticancer, antiviral, antibacterial, antifungal, insecticidal, repellent, antioxidant, reno-protective, anesthetic and analgesic effects. The current review will highlight the chemical constituents and pharmacological effects of Dianthus caryophyllus.

\section{Synonyms:}

\section{I- Plant profile:}

Dianthus acinifolius Schur, Dianthus arbuscula Lindl., Dianthus arrectus Dumort., Dianthus binatus Schur , Dianthus caryophyllus var. coronarius L., Dianthus coronarius (L.) Burm.f., Dianthus corsicus Link ex Spreng., Dianthus kayserianus Schur, Dianthus longicaulis Costa, Dianthus miniatus A.Huet ex Nyman, Dianthus moschatus J.F.Gmel., Dianthus multinervis Vis. and Tunica morrisii (Hance) Walp [61].

Taxonomic classification:

Kingdom: Plantae; Subkingdom: Viridiplantae; Infrakingdom: Streptophyta; Superdivision: Embryophyta; Division: Tracheophyta; Subdivision: Spermatophytina; Class: Magnoliopsida; Superorder: Caryophyllanae; Order: Caryophyllales; Family: Caryophyllaceae; Genus: Dianthus L.; Species: Dianthus caryophyllus[62-63].

\section{Common names:}

Arabic: Gronfel; Burmese: Zaw-hmwa-gyi; Englis Border carnation, Carnation, Clove pink, Divine-flower, Gilly-flower; French: Oeillet, Oeillet des fleuristes; German: Garten-Nelke, Land-Nelke, Nelke; Japanese: Oranda-nadeshiko; Spanish: Clavel; Swedish: Trädgårdsnejlika [64].

\section{Distribution:}

The probable origin of the plant is Mediterranean region [64]. The carnation is a cultivated plant. It is grown worldwide. In Europe, main production countries are Italy, Spain and the Netherlands. Carnation flowers are imported into the Europe from Africa, South America and the Middle East. Wild Dianthus caryophyllus is rare and primarily found in France and Italy [65-66].

\section{Description:}

The plant is annual or perennial, 15-60 cm long, branched, glabrous herb. Leaves are linear lanceolate, apex acute, margin smooth or ciliate at base. Flowers are solitary or in clusters at tips of branches. Epicalyx scales are 4-6 in number, broad-ovate, abruptly mucronate at apex, herbaceous, appressed to calyx, covering one fifth to 
one quarter the length of calyx tube. Calyx tube is cylindrical, 20-30 mm long. Petals are 5, limb exerted, triangular obovate, toothed at apex, auricle absent, pink-red or white, sometimes spotted with darker centers, claw cuneate, glabrous [62, 67-68].

\section{Traditional uses:}

It was used in perfumery, $500 \mathrm{~kg}$ of flowers produce $100 \mathrm{~g}$ of oil [69]. It was used traditionally in the treatment of throat and gum infections, in the treatment of wounds, as cardiotonic, diaphoretic, alexiteric, vermifuge and for the treatment of gastro-intestinal disorder. The plant traditionally used in China, Japan and Korea in the treatment of wounds and gastro-intestinal disorder and various other ailments [67, 70-71]. It was traditionally prescribed in European herbal medicine to treat coronary and nervous disorders. The flowers were considered alexiteric, antispasmodic, cardiotonic, diaphoretic and nervine. The plant has been used as a vermifuge in China [72].For a long time the carnation was used as medicine and spices. It killed a toothache, applied as an antiseptic, at difficulty of breath and eye diseases. Essential oil of a carnation was applied to improve memory and restoring forces. Also oil was used to heal wounds, relieve dizziness and lift appetite [73].

\section{CHEMICAL CONSTITUENTS:}

Phytochemical tests showed that of Dianthus caryophyllus contained triterpenes, alkaloids, coumaruns and cyanogenic glycoside [74]. The major pigments determining carnation flower color were cyanidin, pelargonidin and the yellow isosalipurposide [75-76]. Eac 500kg of flowers produce 100g of oil [69]. The chemical composition and the essential oil of the carnation flowers (Dianthus caryophyllus) was studied. Twelve volatiles were identified by gas chromatography-mass spectrometry (GC-MS) as the main components of carnation flower oil. The major components were phenyl ethyl alcohol, eugenol, hexyl benzoate, hexenyl benzoate, benzyl benzoate, benzoin, nootkatone, benzyl salyicylate, m-cresyl phenyl acetate, hexadecanoic acid and eicosene. There was marked increase in benzyl benzoate from 12.62 to $45.04 \%$, when the plant treated with 200 ppm stigmasterol. The most significant variation of eugenol from (21.48 to $33.54 \%)$ was obtained as a result of treating with $50 \mathrm{ppm}$ stigmasterol and $400 \mathrm{ppm}$ of putrescine [77]. The oil (extracted by organic solvent) of Dianthus caryophyllus grown in Egypt contained four chemical groups: monoterpene hydrocarbons $19.59 \%$ (tricyclene $0.17 \%$, $\alpha$-pinene $2.05 \%$, camphene $0.98 \%, \beta$-pinene $3.11 \%$, phellandrene $3.52 \%, \mathrm{P}$ cymene $3.32 \%$, limonene 4.91 , $\Upsilon$-terpinene $1.53 \%$ ); oxygenated monoterpene $26.71 \%$ (elemol $5.51 \%$, citronellol $1.11 \%$, bornyl acetate $3.12 \%$, eugenol $15.29 \%$, methyl eugenol $1.68 \%$ ); sesquterpenes hydrocarbons $12.83 \%$ ( $Y$-cadinene $4.12 \%$, calamene $8.71 \%$ ) and various compounds $20.97 \%$ ( benzyl benzoate $14.12 \%$, benzyl salicylate $6.85 \%$ ) [78]. Three flavonoids including apigenin-C-glycoside, kaempferol 3-O- $\beta$-dglucopyranosyl- $(1 \rightarrow 2)-\mathrm{O}-[\alpha-1-r h a m n o p y r a n o s y l-(1 \rightarrow 6)]-\beta-d-g l u c o-p y r a n o s i d e \quad$ and kaemp-ferol $3-\mathrm{O}-[\alpha-1-$ rhamnopyranosyl-( $1 \rightarrow 6)]-\beta$-d-glu-copyranoside, were isolated as the main flavonoidal components in nine different carnation cultivars: America, Esperia, Harem, Miledy, Rag-gio di Sole, Roland, Rosa Antico, Tempest, and Tiepolo [79-80].The phenol composition analysis was carried out on healthy and Fusarium oxysporum-inoculated Dianthus caryophyllus tissues in vitro, and on in vivo plants. Two benzoic acid derivatives, protocatechuic acid (3,4- dihydroxybenzoic acid) and vanillic acid (4-hydroxy-3-methoxybenzoic acid), flavonol glycoside peltatoside (3-[6-O-(alpha-L-arabinopyranosyl)-beta-D-glucopyranosyl] quercetin) and flavone datiscetin $\left(3,5,7,2^{\prime}\right.$-tetrahydroxyflavone) were isolated from the plant [81].

Kaempferide triglycoside, was a phenolic compound isolated from Fusarium resistant varieties of Dianthus caryophyllus [82-84].3,5-Di-O-(beta-glucopyranosyl) pelargonidin 6"-O-4,6"'-O-1-cyclic malate and cyanidin equivalent, 3,5-di-O-(beta-glucopyranosyl) cyanidin 6"-O-4,6"'-O-1-cyclic malate were isolated from petals of deep pink and red-purple flower cultivars of Dianthus caryophyllus [85]. Many dianthramides were isolated from Dianthus caryophyllus, all compounds were amides between a benzoic acid (benzoic, salicylic, $\beta$ resorcylic, 4-methoxysalicylic) or a cinnamic acid ( $p$-coumaric) moiety, and an anthranilic acid moiety (anthranilic, 4-hydroxyanthranilic, 4-methoxyanthranilic). However, the amounts of these dianthramides were less importance compared with the amounts of dianthalexin and dianthramides A and B [86]. An antiviral protein was isolated from Dianthus caryophyllus, it contained $\epsilon$-groups of lysine, which were responsible for its antiviral activity. Acid hydrolysis yielded 14 amino acids, none of which contained sulfur [87].Dianthin 30 and dianthin 32, were proteins isolated from the leaves of Diathus caryophyllus, were purified by chromatography on CM-cellulose. The molecular weight of dianthin 30 is 29500 and that of dianthin 32 is 31 700. Both dianthins are glycoproteins containing mannose [88]. Healthy Dianthus caryophyllus stems contained, esterified polysaccharides, benzoic, p-hydroxybenzoic, vanillic, trans p-coumaric, cis and trans ferulic, 3-methoxy-4-hydroxy-n-chlorophenyl propionic and (in large amounts) dihydroferulic acid. Fungal infection affected the concentrations of these phenolic acids and induced accumulation of two types of anthranilic acid derivatives including dianthramides and 2,2'-dicarboxy-5,5'-dihydroxy-N,N-diphenylamine [89].

However, chemical composition of fresh and ensiled carnation ( respectively): dry matter 22.1 and $23.4 \%$; organic matter 90.8 and 89.0 ; crude protein 11.1 and 10.5 ; ether extract 3.1 and 3.4 ; nitrogen free extract 50.5 
and 47.0; crude fiber 25.3 and 28.1; ash 9.1 and 10.9; neutral detergent fiber 43.2 and 44.3; acid detergent fiber 37.0 and 38.0; lignin 10.7 and 9.5; cellulose 28.2 and 28.3 and hemicellulose 6.2 and 6.3 [90].

\section{PHARMACOLOGICAL EFFECTS:}

\section{Anticancer effect:}

Kaempferide triglycoside isolated from Dianthus caryophyllus proved to inhibit the proliferation of native and estrogen receptor $\beta$ overexpressing colon cancer cells through a mechanism not mediated by ligand binding dependent estrogen receptor activation. It affected HCT8 cell cycle progression by increasing the G0/G1 cell fraction and in estrogen receptor $\beta$ overexpressing cells, it increased two important antioxidant proteins metallothionein type 2 (MT2A) and proteins superoxide dismutase type 2 (SOD2). The biological effects of kaempferide triglycoside were strengthened by the presence of high levels of estrogen receptor $\beta$ [83]. A combined application of dianthin coupled to EGF and saponin SO-1861 was tested in a xenograft model of colon carcinoma. In vitro cytotoxicity was tested in real-time in NIH3T3 cells (no human EGF receptor expression), HER14 and human colon carcinoma HCT116 (both EGF receptor overexpressing) cells. A xenograft model was established using HCT116 cells and tumor-bearing animals treated with SO-1861 (30 $\mu \mathrm{g} /$ treatment) and dianthin coupled to EGF $(0.35 \mu \mathrm{g} /$ treatment $)$. Tumor progression was monitored, using (18)F-2-fluor-2-desoxy-d-glucose, by small animal PET and by x-ray computed tomography. In vitro results demonstrated a high-receptor specificity and the in vivo experiment showed a progressive reduction of the tumor volume and glycolytic activity in the treated group $(>95 \%$ reduction; $\mathrm{P}<0.05)$ [91].

\section{Antibacterial and antifungal effects:}

Eugenol was isolated from the essential oils of the plant and investigated for its antibacterial activities against seven selected pathogenic bacteria (Staphylococcus aureus, Bacillus cereus, Listeria monocytogenes, Proteus mirabilis, Escherichia coli, Klebsiella pneumoniae and Pseudomonas aeruginosa). Eugenol achieved strong MIC values against most tested pathogens and the best MIC value (15.6 microg/ml) was observed against B. cereus, L. monocytogenes and $K$. pneumoniae whereas, S. aureus, P. mirabilis and E. coli were inhibited with a MIC value of $31.2 \mathrm{microg} / \mathrm{ml}$ [71]. Whole Dianthus caryophyllus extracts showed antibacterial activity against Staphylococcus epidermidis, Klebsiella pneumonia and Bordetella bronchiseptica [92].Standard bacterial strains included [Pseudomonas aeruginosa (PTCC No. 1074), P. fluorescens (PTCC No. 1181), Bacillus subtilis (PTCC No. 1023), B. cereus (PTCC No. 1015) and B. pumilis (PTCC No. 1319)] were used to evaluate the antibacterial activity of Dianthus caryophyllus. Dianthus caryophyllus (the whole plant, methanolic extract) was the most active plant, among 180 tested plants, against all tested bacterial species, with MIC of $1.87,7.5,3.72,3.75$ and $0.46 \mathrm{mg} / \mathrm{ml}$ against B. subtilis, B. cereus, B. pumilis, $P$. aeruginosa and $P$. fluorescens respectively [93].Aqueous and methanolic extracts of aerial parts of Dianthus caryophyllus showed anti-Helicobacter pylori activity with $\mathrm{MIC}>1000$ and $>500 \mu \mathrm{g} / \mathrm{ml}$ respectively [94]. Two benzoic acid derivatives, protocatechuic acid (3,4-dihydroxybenzoic acid) and vanillic acid (4-hydroxy-3-methoxybenzoic acid), isolated from Dianthus caryophyllus were slightly inhibitory towards F. oxysporum, while the highly resistant cultivar "Roland" showed the presence of the flavone datiscetin (3,5,7,2'-tetrahydroxyflavone). which exhibited an appreciable fungitoxic activity towards $F$. oxysporum f. sp. dianthi [81].

\section{Antiviral effect:}

Crude extract of Dianthus caryophyllus was tested for their antiviral activity against herpes simplex virus-1 (HSV-1) and hepatitis A virus-27 (HAV-27). Non-toxic concentration (20 $\mu \mathrm{g} / \mathrm{ml})$ of Dianthus caryophyllus seed extract to both Vero and HepG2 cells showed potent antiviral activity against HSV-1 and HAV-27 using plaque infectivity count assay. No effect was detected for the extract on adsorption or on the stages of virus replication. A comparison has been done between the antiviral activity of two therapeutic drugs (acyclovir and amentadine used as controls for HSV-1 and HAV-MBB, respectively) and the tested seed extract. The results revealed that the seed extract was more efficient in its inhibitory activity than synthetic chemical drugs against the same viruses [95]. An antiviral protein was isolated from Dianthus caryophyllus, it contained $\epsilon$-groups of lysine, which were responsible for the antiviral activity of the molecule. Acid hydrolysis yielded 14 amino acids, none of which contained sulfur. Its viral inhibitory activity was unchanged after incubation with 4 proteolytic enzymes. The protein was also protected Nicotiana glutinosa L. from infection by either intact tobacco mosaic virus (TMV) or the infectious nucleic acid (RNA) derived from it, it possessed no ribonuclease (RNase) activity, and unable to prevent enzymatic breakdown of RNA by pancreatic RNase. The authors postulated that the protein competed via its $\epsilon$-amino groups with similar groups in complete TMV and certain amino groups in RNA for essential sites in the host. These sites of common importance to both virus and infectious RNA in the early phases of virus establishment [87].A highly potent inhibitor of virus infection was isolated from Dianthus caryophyllus. Inhibitor solutions obtained at an organic matter at a concentration as 
low as $0.66 \mu \mathrm{g} / \mathrm{ml}$ completely suppressed local lesion development of a $0.06 \%$ TMV preparation on Nicotiana glutinosa L. Based upon dry weight and biological activity of carnation sap that had been centrifuged at low speed, the purification procedure resulted in a 15000-fold increase in activity per unit dry matter [96].Three inhibitors of human immunodeficiency virus (HIV) have been isolated and purified from Euphorbiaceae himalaya seeds (Gelonium multiflorum) and carnation leaves (Dianthus caryophyllus). These proteins, GAP 31 (Gelonium Anti-HIV Protein $31 \mathrm{kDa}$ ) and DAPs 30 and 32 (dianthus anti-HIV proteins, 30 and $32 \mathrm{kDa}$ ), inhibit HIV-1 infection and replication in a dose-dependent manner with little toxicity to target cells [97]. Dianthin 30 and dianthin 32 inhibited protein synthesis in a lysate of rabbit reticulocytes, with an ID $_{50}$ of $9.15 \mathrm{ng} / \mathrm{ml}$ (dianthin 30) and $3.6 \mathrm{ng} / \mathrm{ml}$ (dianthin 32). They act by damaging ribosomes in a less-than-equimolar ratio. Protein synthesis by intact cells is partially inhibited by dianthins at a concentration of $100 \mathrm{microgram} / \mathrm{ml}$. Dianthins mixed with tobacco-mosaic virus strongly decrease the number of local lesions on leaves of Nicotiana glutinosa [98].

\section{Insecticidal and repellent effect:}

The larvicidal effect exhibited by essential oils of Dianthus caryophyllus was studied against late third to early fourth instar mosquito larvae of Culex pipiens. The essential oils of Dianthus caryophyllus also exerted moderate larvicidal activity, displaying $\mathrm{LC}_{50}$ value above $50 \mathrm{mg} / \mathrm{l}$. Among the pure components, the most toxic were eugenol, (E)-anethole, and $\alpha$-terpinyl acetate, with $\mathrm{LC}_{50}$ value of 18.28, 16.56, and $23.03 \mathrm{mg} / \mathrm{l}$, respectively [99]. The essential oil from flowers of carnation (Dianthus caryophyllum ) exerted pronounced repellent effect both against both ticks (nymphs of Ixodes ricinus) and yellow fever mosquitoes (Aedes aegypti). Phenylethanol was found the most potent repellents ingredient [100].

\section{Antioxidant effect:}

The scavenging effect of volatile oil of Dianthus caryophyllus flowers was studied using DPPH assay. The plant possessed scavenging effect, but when it was treated with $400 \mathrm{ppm}$ stigmasterol, it gave the highest scavenging activity [77].

\section{Reno-protective effect:}

The inhibitory effect of Dianthus caryophyllus extract on renal failure induced by gentamicin was investigated in rats. Dianthus caryophyllus ethanol $96 \%$ extract was able to protect the enzyme changes and nephrotoxicity induced by gentamicin. This protective effect may be related to the antioxidant properties of these extracts [101].

\section{Pharmacology of Eugenol:}

Eugenol was the major constituent of clove oils. It was a member of the ally benzene class of chemical compounds. It was a weak acidic, slightly soluble in water and soluble in organic solvents. It was a clear to pale yellow liquid with characteristic and pleasant odor of cloves and a spicy pungent taste. Many studies have been performed to evaluate the pharmacological properties of eugenol. It possessed strong antioxidant activity which due to the presence of the phenolic group. Allyl group in the structure of eugenol is responsible for scavenging effect. Eugenol also interfered with initiation as well as propagation of lipid peroxidation and this effect also participated in the free radical scavenging effect of eugenol [102]. The anesthetic and analgesic activity of eugenol were attributed to its ion channel blocking properties. Eugenol blocked $\mathrm{Ca}^{+2}, \mathrm{Na}^{+}$and $\mathrm{K}^{+}$ channels in trigeminal ganglion neurons including dental afferent neurons, inhibits PGE2 and interleukin $1 \beta$ synthesis (this inhibition was independent of TRPV1), possessed an agonistic effect on $\gamma$-aminobutyric acid and antagonized NMDA glutamate receptor, therefore, eugenol was widely used as anesthetic and analgesic in dentistry [103-106]. Eugenol inhibited A $\beta$-induced excessive influx of calcium ion into neurons that caused neuronal death. In addition, it possessed an antidepressant-like activity. Eugenol increases expression of brainderived neurotrophic factor (BDNF) gene in the hippocampus, which was necessary for an antidepressant to exhibit its activity. It also inhibited monoamine oxidase A (MAO-A) and may restore monoamines that were decreased in the brain of patients with depression [107].It was also possessed anti-inflammatory effects via inhibition of nitric oxide production, blocking the release of interleukin 1- $\beta$, TNF- $\alpha$ and PG E2 from stimulated macrophages [108-109]. Many antibacterial studies revealed that eugenol possessed a wide range of antibacterial effects against Gram positive (Bacillus cereus, B. subtilis, Staphylococcus aureus, Staphylococcus epidermidis, Streptococcus pneumoniae and Streptococcus pyogenes) and Gram negative (Escherichia coli, Salmonella typhi, Pseudomonas aeruginosa and Helicobacter pylori) [110-113].Eugenol also inhibited adherence and biofilms of two pathogenic P. aeruginosa isolates. Eugenol $(0.5 \%)$ caused $60 \%$ adherence inhibition for $P$. aeruginosa (CIP A22) and 69\% for $P$. aeruginosa (ATCC27853). Inhibition of more than $90 \%$ was obtained when eugenol was tested against $P$. aeruginosa (ATCC 27853) biofilms [114].

Eugenol showed activity against biofilm of candidal infections refractory to the antifungal agents. Eugenol altered the morphogenesis of the envelope of $C$. albicans which was pivotal in mediating the initial 
physicochemical interactions between the fungus and its environment [115-117]. When eugenol combined with vancomycin and $\beta$-lactam antibiotics, this combination revealed an increased activity 5-1000 times compared to their individual MIC. It appeared that eugenol damaged the membrane of bacteria and allowing increased penetration of antibiotics [118-120]. Eugenol also possessed killing or repellent action on worldwide agricultural insects [121-122].Eugenol in doses ( $10-100 \mathrm{mg} / \mathrm{kg}$ ) also possessed anti-ulcerogenic effects in gastric ulcers induced by different ulcerogenic agents. The gastroprotective effect could be attributed to the opening of ATP-sensitive potassium $\left(\mathrm{K}^{+}-\mathrm{ATP}\right)$ channels, free radical scavenging, decreased acid-pepsin secretion, increased mucin production and prevention of the deleterious rise in nitric oxide level [123-124]. Eugenol also possessed antidiarrhoeal effects in diarrhoea induced by castor oil, It also induced relaxant effects on isolated gut muscle [125-126]. Eugenol also induced relaxant effects of myometrium and airway smooth muscle of rats. It blocks voltage- and receptor-operated $\mathrm{Ca}^{2+}$ channels, IP 3-induced $\mathrm{Ca}^{2+}$ release from sarcoplasmic reticulum and reduction of the sensitivity of contractile proteins to $\mathrm{Ca}^{2+}$ [126-127]. When HL-60 cell incubated with eugenol, it induced DNA fragmentation (a gradual increase of fragmented DNA could be observed). A ladder pattern of internucleosomal DNA fragmentation was also apparent when cells were treated for $4 \mathrm{~h}$ with $40 \mu \mathrm{M}$ of eugenol. Eugenol induced apoptosis in HL-60 cells via reactive oxygen species generation, by inducing mitochondrial permeability transition, by reducing anti-apoptotic protein bcl-2 level and cytochrome $c$ release to the cytosol as well as subsequent apoptosis [128].Eugenol inhibited the proliferation of melanoma cells and prostate cancer cells by blocking the cells in the G0/G1 phase of the cell cycle [129-130]. Eugenol $(500 \mu \mathrm{M})$ reduced cell viability of HeLa cells. It showed dose-dependent selective cytotoxicity towards HeLa cells in comparison to normal cells. Furthermore, eugenol and gemcitabine in combination induced growth inhibition and apoptosis at lower concentrations in comparison to the individual compounds which indicated synergistic interactions [131-132]. The antioxidant and free radical scavenging activity of 6bromoeugenol and eugenol was studied using 2,2-diphenyl-1-picrylhydrazyl (DPPH) radical-scavenging method. EC $_{50}$ values of 6-bromoeugenol, ascorbic acid and eugenol were 34.270, 54.888 and $130.485 \mu \mathrm{g} / \mathrm{ml}$, respectively. 6-Bromoeugenol showed higher AAI value (1.122) followed by ascorbic acid (0.700), then by eugenol (0.295) [133]. The cardiovascular effects of intravenous treatment with eugenol, were investigated in normotensive rats. In either anesthetized or conscious rats, intravenous bolus injections of Eugenol (1 to 10 $\mathrm{mg} / \mathrm{kg}$ ) elicited immediate and dose-dependent hypotension and bradycardia. Magnitude of Eugenol-induced hypotension was similar in both groups. Pretreatment of anesthetized rats with bilateral vagotomy almost abolished the bradycardic responses to Eugenol without affecting the hypotension. Likewise, iv pretreatment of conscious rats with methylatropine $(1 \mathrm{mg} / \mathrm{kg})$ or hexamethonium $(30 \mathrm{mg} / \mathrm{kg})$ significantly reduced the Eugenolinduced bradycardia without affecting the hypotension. However, iv pretreatment with the nitric oxide synthase inhibitor, NG-nitro-L-arginine methyl (L-NAME, $20 \mathrm{mg} / \mathrm{kg}$ ), affected neither the hypotension nor the bradycardia elicited by Eugenol [134].

\section{Contraindications and side effects:}

Pregnant women and nursing mothers should not apply a carnation. It was strong spice therefore it cannot be given to children below two years. Hypertensive persons also have to refrain from its application. At an ulcer, gastritis it is possible to use a carnation, but only in small doses [73]. Occupational exposure to Dianthus caryophyllus may cause allergic and asthmatic manifestations. A total of 16 subjects employed in indoor carnation cultivation with symptoms during exposition time were studied along with 15 patients with allergic asthma who were not exposed to carnations and 15 healthy carnation workers used as control subjects. Skin prick test responses with carnation extract were positive in 15 of the 16 patients and negative in all control subjects. Nasal provocation test responses with carnation extract were positive in 13 of 16 patients. A significant correlation was seen between RAST and nasal provocation results $(\mathrm{P}<0.01)$. Immunoblotting of sera from 13 patients showed 2 major IgE-binding fractions of 34 and $35 \mathrm{kd}$ in most of the patients, which could constitute the major allergen [135]. Eugenol was not free from adverse side effects. Eugenol has a corrosive action, cause respiratory syndrome, and its ingestion can cause metabolic acidosis. In infants, eugenol can cause hypoglycemia and liver failure, protein and hematotoxicity with disseminated intravascular coagulation. Animal experiments showed that eugenol can cause gastroenteritis and anorexia [136].

\section{CONCLUSION}

The current review highlights the chemical constituents, pharmacological importance of Dianthus caryophyllus as promising herbal drug because of its safety and effectiveness.

\section{REFERENCES:}

[1] Al-Snafi AE. A review on Erodium cicutarium: A potential medicinal plant. Indo Am J P Sci 2017; 4(01): 110-116.

[2] Al-Snafi AE. Pharmacology of Echinochloa crus-galli - A review. Indo Am J P Sci 2017; 4(01): 117122 . 
[3] Al-Snafi AE. The pharmacological potential of Dactyloctenium aegyptium- A review. Indo Am J P Sci 2017; 4(01): 153-159.

[4] Al-Snafi AE. Chemical constituents, pharmacological and therapeutic effects of Eupatorium cannabinum- A review. Indo Am J P Sci 2017; 4(01): 160-168.

[5] Al-Snafi AE. Nutritional and therapeutic importance of Daucus carota- A review. IOSR Journal of Pharmacy 2017; 7(2): 72-88.

[6] Al-Snafi AE. Chemical constituents and pharmacological effects of Dalbergia sissoo - A review. IOSR Journal of Pharmacy 2017; 7(2): 59-71.

[7] Al-Snafi AE. Medical importance of Datura fastuosa (syn: Datura metel) and Datura stramonium - A review. IOSR Journal of Pharmacy 2017; 7(2):43-58.

[8] Al-Snafi AE. A review on Dodonaea viscosa: A potential medicinal plant. IOSR Journal of Pharmacy 2017; 7(2): 10-21.

[9] Al-Snafi AE. The pharmacology and medical importance of Dolichos lablab (Lablab purpureus)- A review. IOSR Journal of Pharmacy 2017; 7(2): 22-30.

[10] Al-Snafi AE. Pharmacological and therapeutic importance of Desmostachya bipinnata- A review. Indo Am J P Sci 2017; 4(01): 60-66.

[11] Al-Snafi AE. Chemical constituents and pharmacological effects of Eryngium creticum- A review. Indo Am J P Sci 2017; 4(01): 67-73.

[12] Al-Snafi AE. The pharmacology of Equisetum arvense- A review. IOSR Journal of Pharmacy 2017; 7(2): 31-42.

[13] Al-Snafi AE. Clinically tested medicinal plant: A review (Part 1). SMU Medical Journal 2016; 3(1): 99128.

[14] Al-Snafi AE. Medicinal plants possessed anti-inflammatory antipyretic and analgesic activities (part 2)plant based review. Sch Acad J Pharm 2016; 5(5): 142-158.

[15] Al-Snafi AE. Medicinal plants affected reproductive systems (part 2) - plant based review. Sch Acad J Pharm 2016; 5(5): 159-174. http://saspublisher.com/wp-content/uploads/2016/06/SAJP-55159-174.pdf

[16] Al-Snafi AE. Medicinal plants with anticancer effects (part 2)- plant based review. Sch Acad J Pharm 2016; 5(5): 175-193. http://saspublisher.com/wp-content/uploads/2016/06/SAJP-55175-193.pdf

[17] Al-Snafi AE. Antiparasitic, antiprotozoal, molluscicidal and insecticidal activity of medicinal plants (part 2) - plant based review. Sch Acad J Pharm 2016; 5(6): 194-207. http://saspublisher.com/wpcontent/uploads/2016/07/SAJP-56194-207.pdf

[18] Al-Snafi AE. Medicinal plants with antidiabetic effects (part 2): plant based review. IOSR Journal of Pharmacy 2016; 6(7): 49-61.

[19] Al-Snafi AE. Medicinal plants with antioxidant and free radical scavenging effects (part 2): plant based review. IOSR Journal Of Pharmacy 2016; 6(7): 62-82.

[20] Al-Snafi AE. Medicinal plants with antimicrobial activities (part 2): Plant based review. Sch Acad J Pharm 2016; 5(6): 208-239.

[21] Al-Snafi AE. Medicinal plants with cardiovascular effects (part 2): plant based review. IOSR Journal of Pharmacy 2016; 6(7): 43-62.

[22] Al-Snafi AE. Detoxification capacity and protective effects of medicinal plants (part 2): plant based review. IOSR Journal of Pharmacy 2016; 6(7): 63-84.

[23] Al-Snafi AE. Beneficial medicinal plants in digestive system disorders (part 2): plant based review. IOSR Journal of Pharmacy 2016; 6(7): 85-92. http://www.iosrphr.org/papers/v6i7V3/G067038592.pdf

[24] Al-Snafi AE. A review of medicinal plants with broncho-dilatory effect-Part 1. Scholars Academic Journal of Pharmacy 2015; 5(7): 297-304.

[25] Al-Snafi AE. Medicinal plants with central nervous effects (part 2): plant based review. IOSR Journal of Pharmacy 2016; 6(8): 52-75. http://www.iosrphr.org/papers/v6i8V1/G068015275.pdf

[26] Al-Snafi AE. Immunological effects of medicinal plants: A review (part 2). Immun Endoc \& Metab Agents in Med Chem 2016; 16(2): 100-121. http://www.eurekaselect.com/146338

[27] Al-Snafi AE. Medicinal plants affected male and female fertility (part 1)- A review. IOSR Journal of Pharmacy 2016; 6(10): 11-26. www.iosrphr.org/papers/v6i10V3/C0610031126.pdf

[28] Al-Snafi AE. Antiparasitic effects of medicinal plants (part 1)- A review. IOSR Journal of Pharmacy 2016; 6(10): 51-66. http://www.iosrphr.org/papers/v6i10V3/H0610035166.pdf

[29] Al-Snafi AE. Antimicrobial effects of medicinal plants (part 3): plant based review. IOSR Journal of Pharmacy 2016; 6(10): 67-92. http://www.iosrphr.org/papers/v6i10V3/I0610036792.pdf.

[30] Al-Snafi AE. The constituents and pharmacology of Corchorus aestuans: A review. The Pharmaceutical and Chemical Journal 2016; 3(4):208-214. http://tpcj.org/download/vol-3-iss-4-2016/TPCJ2016-03-04208-214.pdf 
[31] Al-Snafi AE. The chemical constituents and pharmacological activities of Cymbopagon schoenanthus: A review. Chemistry Research Journal 2016; 1(5):53-61. http://chemrj.org/download/vol-1-iss-52016/chemrj-2016-01-05-53-61.pdf

[32] Al-Snafi AE. Traditional uses, constituents and pharmacological effects of Cuscuta planiflora. The Pharmaceutical and Chemical Journal 2016; 3(4): 215-219. http://tpcj.org/download/vol-3-iss-42016/TPCJ2016-03-04-215-219.pdf

[33] Al-Snafi AE. A review on Fagopyrum esculentum: A potential medicinal plant. IOSR Journal of Pharmacy 2017; 7(3): 21-32.

[34] Al-Snafi AE. Nutritional and pharmacological importance of Ficus carica - A review. IOSR Journal of Pharmacy 2017; 7(3): 33-48.

[35] Al-Snafi AE. The pharmacological Importance of Antirrhinum majus - A review. Asian J of Pharm Sci \& Tech 2015; 5(4): 313-320. http://www.ajpst.com/File_Folder/313-320.pdf

[36] Al-Snafi AE. The pharmacological importance of Centaurea cyanus- A review. Int J of Pharm Rev \& Res 2015; 5(4): 379-384. http://www.ijprr.com/File_Folder/379-384.pdf

[37] Al-Snafi AE. The chemical constituents and pharmacological importance of Chrozophora tinctoria. Int J of Pharm Rev \& Res 2015; 5(4): 391-396. http://www.ijprr.com/File_Folder/391-396.pdf

[38] Al-Snafi AE. Chemical constituents and pharmacological importance of Agropyron repens - A review. Research Journal of Pharmacology and Toxicology 2015; 1 (2): 37-41.

[39] Al-Snafi AE. Pharmacology and therapeutic potential of Euphorbia hirta (Syn: Euphorbia pilulifera) - A review. IOSR Journal of Pharmacy 2017; 7(3): 7-20.

[40] Al-Snafi AE. Medical importance of Cichorium intybus - A review . IOSR Journal of Pharmacy 2016; 6(3): 41-56. http://www.iosrphr.org/papers/v6i3/E0634156.pdf

[41] Al-Snafi AE. Pharmacological importance of Clitoria ternatea - A review. IOSR Journal of Pharmacy 2016; 6(3): 68-83. http://www.iosrphr.org/papers/v6i3/G0636883.pdf

[42] Al-Snafi AE. The medical Importance of Cicer arietinum - A review. IOSR Journal of Pharmacy 2016; 6(3): 29-40. http://www.iosrphr.org/papers/v6i3/D0632940.pdf

[43] Al-Snafi AE. Medical importance of Anthemis nobilis ( Chamaemelum nobilis)- A review. Asian Journal of Pharmaceutical Science \& Technology 2016; 6(2): 89-95. http://www.ajpst.com/File_Folder/8995(ajpst).pdf

[44] Al-Snafi AE. Adonis aestivalis: pharmacological and toxicological activities- A revew. Asian Journal of Pharmaceutical Science \& Technology 2016; 6(2): 96-102. http://www.ajpst.com/File_Folder/96102(ajpst).pdf

[45] Al-Snafi AE. Pharmacological and therapeutic importance of Echium italicum- A review. Indo Am J P Sci 2017; 4(02): 394-398.

[46] Al-Snafi AE. Therapeutic importance of Ephedra alata and Ephedra foliata- A review. Indo Am J P Sci 2017; 4(02): 399-406.

[47] Al-Snafi AE. Therapeutic potential of Erodium cicutarium - A review. Indo Am J P Sci 2017; 4(02): $407-$ 413.

[48] Al-Snafi AE. The medical importance of Cydonia oblonga- A review. IOSR Journal of Pharmacy 2016; 6(6): 87-99. http://www.iosrphr.org/papers/v6i6V2/J066028799.pdf

[49] Al-Snafi AE. The pharmacology of Crocus sativus- A review. IOSR Journal of Pharmacy 2016; 6(6): 838. http://www.iosrphr.org/papers/v6i6V3/C06630838.pdf

[50] Al-Snafi AE. The chemical constituents and therapeutic importance of Cressa cretica- A review . IOSR Journal of Pharmacy 2016; 6(6): 39-46. http://www.iosrphr.org/papers/v6i6V3/D06633946.pdf

[51] Al-Snafi AE. The Pharmacological and therapeutic importance of Cordia myxa- A review. IOSR Journal of Pharmacy 2016; 6(6): 47-57. http://www.iosrphr.org/papers/v6i6V3/E06634757.pdf

[52] Al-Snafi AE. The contents and pharmacological importance of Corchorus capsularis- A review. IOSR Journal of Pharmacy 2016; 6(6): 58-63. http://www.iosrphr.org/papers/v6i6V3/F06635863.pdf

[53] Al-Snafi AE. The chemical constituents and pharmacological effects of Convolvulus arvensis and Convolvulus scammonia- A review. IOSR Journal of Pharmacy 2016; 6(6): 64-75. http://www.iosrphr.org/papers/v6i6V3/G06636475.pdf

[54] Al-Snafi AE. A review on chemical constituents and pharmacological activities of Coriandrum sativum. IOSR Journal of Pharmacy 2016; 6(7): 17-42. http://www.iosrphr.org/papers/v6i7V3/D067031742.pdf

[55] Al-Snafi AE. Pharmacology and toxicology of Conium maculatum- A review. The Pharmaceutical and Chemical Journal 2016; 3(2):136-142. http://tpcj.org/download/vol-3-iss-2-2016/TPCJ2016-03-02-136142.pdf

[56] Al-Snafi AE. The constituents and pharmacology of Cnicus benedictus- A review. The Pharmaceutical and Chemical Journal 2016; 3(2):129-135. http://tpcj.org/download/vol-3-iss-2-2016/TPCJ2016-03-02129-135.pdf 
[57] Al-Snafi AE. Medicinal importance of Colchicum candidum- A review. The Pharmaceutical and Chemical Journal 2016; 3(2):111-117. http://tpcj.org/download/vol-3-iss-2-2016/TPCJ2016-03-02-111117.pdf

[58] Al-Snafi AE. Nutritional value and pharmacological importance of citrus species grown in Iraq. IOSR Journal of Pharmacy 2016; 6(8): 76-108. http://www.iosrphr.org/papers/v6i8V1/H0680176108.pdf

[59] Al-Snafi AE. The pharmacological and toxicological effects of Coronilla varia and Coronilla scorpioides: A review. The Pharmaceutical and Chemical Journal 2016; 3(2): 105-114. http://tpcj.org/download/vol-3-iss-3-2016/TPCJ2016-03-03-105-114.pdf

[60] Al-Snafi AE. Pharmacological activities of Cotoneaster racemiflorus- A review. The Pharmaceutical and Chemical Journal 2016, 3(2):98-104. http://tpcj.org/download/vol-3-iss-3-2016/TPCJ2016-03-0398-104.pdf

[61] The plant list, a working list of all plant species, Dianthus caryophyllus, http://www. theplantlist.org/tpl/record/kew-2764005

[62] Shishkin BK. Dianthus L. In: Flora of the USSR: Centrospermae, Vol 6, Shishkin, BK. (ed.). Isdatel stvo Akademii Nauk SSSR, Moscow, Russia 1970: 643-644.

[63] ITIS taxonomy report, Dianthus caryophyllus, http://www.itis.gov/servlet/Single Rpt/ SingleRpt?search_topic=TSN\&search_value $=506587$

[64] U.S. National Plant Germplasm System, Dianthus caryophyllus L. https://npgsweb. arsgrin.gov/gringlobal/taxonomydetail.aspx?13826

[65] Chandler S. Application to import cut-flowers of carnation (Dianthus caryophyllus) line SHD-27531-4 for distribution and retail under directive 2001/18/EC, gmoinfo.jrc.ec.europa.eu/csnifs/C-NL-13-01.f

[66] Cumo C. Encyclopedia of cultivated plants: from Acacia to Zinnia. ABC-CLIO, Santa Barbara, CA 2013: 218-122.

[67] Chandra S, Rawat DS, Chandra D and Rastogi J. Nativity, phytochemistry, ethnobotany and pharmacology of Dianthus caryophyllus. Research Journal of Medicinal Plant 2016; 10 (1): 1-9.

[68] Ghazanfar SA. Caryophyllaceae. Pan Graphics, Islamabad, Pakistan 1986: 124.

[69] Usher G. A dictionary of plants used by man. Macmillan Pub Co 1974.

[70] Al-Rawi A and Chakravarty L. Medicinal plants of Iraq. $2^{\text {nd }}$ ed., Ministry of Agriculture, Baghdad 1988: 93.

[71] Mohammed MJ and Al-Bayati FA. Isolation and identification of antibacterial compounds from Thymus kotschyanus aerial parts and Dianthus caryophyllus flower buds. Phytomedicine 2009; 16: 632-637.

[72] Medicinal herbs, Carnation, Dianthus caryophyllus, http://www.natural medicinalherbs.net/herbs/d/dianthus-caryophyllus=carnation.php

[73] Natural and alternative treatment. Carnation - types of a carnation, medicinal properties, application of a carnation. Properties of essential oil of a carnation. http://herbalthera.com/carnation-types-of-a-carnationmedicinal-properties application-of-a-carnation-properties-of-essential-oil-of-a-carnation/ [Dec 17, 2015]

[74] Eltayeb RA. Study of some chemical constituents of Dianthus caryophyllus and Elettaria Cardamomum. Thesis, University of Khartoum 2016.

[75] Forkmann G and Dangelmayr B. Genetic control of chalcone isomerase activity in flowers of Dianthus caryophyllus. Biochem Genet 1980; 18: 519-527.

[76] Forkmann G. Flavonoid as flower pigments: the formation of the natural spectrum and its extension by genetic engineering. Plant Breeding 1990; 106: 1-26.

[77] El-Ghorab AH, Mahgoub $\mathrm{MH}$ and Bekheta M. Effect of some bioregulators on the chemical composition of essential oil and its antioxidant activity of Egyptian carnation (Dianthus caryophyllus L.). Journal of Essential Oil Bearing 2006; 9(3): 214-222.

[78] Ibrahim ME. Agrochemical studies on Dianthus caryophyllus L. grown in Egypt. Int J PharmTech Res 2016; 9(4): 113-117.

[79] Galeotti F, Barile E, Lanzotti V, Dolci M and Curir P. Quantification of major flavonoids in carnation tissues (Dianthus caryophyllus) as a tool for cultivar discrimination. Z Naturforsch C 2008; 63(3-4):161168.

[80] Galeotti F, Barile E, Curir P, Dolci M and Lanzotti V. Flavonoids from carnation (Dianthus caryophyllus) and their antifungal activity. Phytochemistry Letters 2008; 1: 44-48.

[81] Curir P, Dolci M, Dolci P, Lanzotti V and De Cooman L. Fungitoxic phenols from carnation (Dianthus caryophyllus) effective against Fusarium oxysporum f. sp. dianthi. Phytochem Anal 2003;14(1):8-12.

[82] Curir PM. Lanzotti DV and Taglialatela-Scafati O. Kaempferide triglycoside: A possible factor of resistance of carnation (Dianthus caryophyllus) to Fusarium oxysporum f. sp. dianthi. Phytochemistry 2001; 56: 717-721.

[83] Martineti V, Tognarini I, Azzari C, et al. Inhibition of in vitro growth and arrest in the G0/G1 phase of HCT8 line human colon cancer cells by kaempferide triglycoside from Dianthus caryophyllus. Phytother Res 2010; 24:1302-1308. 
[84] Ardila HD, Martinez ST and Higuera PL. Levels of constitutive flavonoid biosynthetic enzymes in carnation (Dianthus caryophyllus L.) cultivars with differential response to Fusarium oxysporum $\mathrm{f}$. sp. dianthi. Acta Physiologiae Plantarum 2013; 35: 1233-1245.

[85] Nakayama M, Koshioka M, Yoshida H, Kan Y, Fukui Y, Koike A and Yamaguchi M. Cyclic malyl anthocyanins in Dianthus caryophyllus. Phytochemistry 2000; 55(8): 937-939.

[86] Ponchet M, Favre-Bonvin J, Hauteville M and Ricci P. Dianthramides (N-benzoyl and Nparacoumarylanthranilic acid derivatives) from elicited tissues of Dianthus caryophyllus. Phytochemistry 1988; 27(3):725-730.

[87] Ragetli HWJ and Weintraub M. Purification and characteristics of a virus inhibitor from Dianthus caryophyllus L.: II. Characterization and mode of action. Virology 1962; (2): 241-248.

[88] Stirpe F, Williams DG, Onyon LG, Legg RF and Stevens WA. Dianthins, ribosome-damaging proteins with anti-viral properties from Dianthus caryophyllus L. (carnation) Biochemical Journal 1981; 195 (2): 399-405.

[89] Niemann GJ, van der Kerk A, Niessen WMA and Versluis K. Free and cell wall-bound phenolics and other constituents from healthy and fungus-infected carnation (Dianthus caryophyllus L.) stems. Physiological and Molecular Plant Pathology 1991; 38(6): 417-432.

[90] Ceron JJ, Hernhdez b, Madridez J and Gutiherrez C. Chemical composition and nutritive value of fresh and ensiled carnation (Dianthus caryophyllus) by-product. Small Ruminant Research 1996; 20:109-1 12.

[91] Von Mallinckrodt B, Thakur M, Weng A, Gilabert-Oriol R, Dürkop H, Brenner W, Lukas M, Beindorff N, Melzig MF and Fuchs H. Dianthin-EGF is an effective tumor targeted toxin in combination with saponins in a xenograft model for colon carcinoma. Future Oncol 2014;10(14):2161-2175.

[92] Bonjar S. Evaluation of antibacterial properties of some medicinal plants used in Iran. J Ethnopharmacol 2004; 94:301-305.

[93] Bonjar GHS, Nik AK, Heydari MR, Ghasemzadeh MH, Farrokhi PR, Moein MR, Mansouri S and Foroumadi A. Anti-pseudomona and anti-bacilli activity of some medicinal plants of Iran. DARU 2003;11 (4): 157-163.

[94] Castillo-Juarez, I, Gonzalez V, Jaime-Aguilar H, Martinez G, Linares E, Bye R and Romero I. AntiHelicobacter pylori activity of plants used in mexican traditional medicine for gastrointestinal disorders. Ethnopharmacol 2009; 122: 402-405.

[95] Barakat AB, Shoman SA, Dina N and Alfarouk OR. Antiviral activity and mode of action of Dianthus caryophyllus L. and Lupinus termes L. seed extracts against in vitro herpes simplex and hepatitis A viruses infection. J Microbiol Antimicrob 2010; 2:23-29.

[96] Ragetli HWJ and Weintraub M. Purification and characteristics of a virus inhibitor from Dianthus caryophyllus L.: I. Purification and activity. Virology 1962; 18(2): 232-240.

[97] Lee-Huang S, Kung HF, Huang PL, Huang PL, Li BQ, Huang P, Huang HI and Chen HC. A new class of anti-HIV agents: GAP31, DAPs 30 and 32. FEBS Lett 1991; 291(1): 139-144.

[98] Stirpe F, Williams DG, Onyon LJ, Legg RF and Stevens WA. Dianthins, ribosome-damaging proteins with anti-viral properties from Dianthus caryophyllus L. (carnation). Biochemical Journal 1981; 195 (2): 399-405.

[99] Kimbaris AC, Koliopoulos G, Michaelakis A and Konstantopoulou MA. Bioactivity of Dianthus caryophyllus, Lepidium sativum, Pimpinella anisum, and Illicium verum essential oils and their major components against the West Nile vector Culex pipiens. Parasitol Res 2012;111(6):2403-2410.

[100] Tunón H, Thorsell W, Mikiver A and Malander I. Arthropod repellency, especially tick (Ixodes ricinus), exerted by extract from Artemisia abrotanum and essential oil from flowers of Dianthus caryophyllum. Fitoterapia 2006; 77(4):257-261.

[101] Mosaffa JH, Najafian M and Jahromiv H. Inhibitory effects of Dianthus caryophyllus extract on gentamicin- induced neprotoxicity in adult rats. IJBPAS 2013; 2(8): 1678-1690.

[102] Ogata M, Hoshi M, Urano S and Endo T, Antioxidant activity of eugenol and related monomeric and dimeric compounds. Chem Pharm Bull 2000; 48: 1467-1469.

[103] Park CK, Li HY, Yeon KY, Jung SJ, Choi SY, Lee SJ, Lee S, Park K, Kim JS and Oh SB. Eugenol inhibits sodium currents In dental afferent neurons. J Dent Res 2006; 85: 900-909.

[104] Li HY, Park CK, Jung SJ, Choi SY, Lee SJ, Park K, Kim JS and Oh SB. Eugenol inhibits $\mathrm{K}^{+}$currents in trigeminal ganglion neurons. J Dent Res 2007; 86: 898-902.

[105] Aoshima $\mathrm{H}$ and Hamamoto $\mathrm{K}$, Potentiation of $\mathrm{GABA}_{\mathrm{A}}$ receptors expressed in Xenopus oocytes by perfumes and phytoncid. Biosci Biotechnol Biochem 1999; 63: 743-748.

[106] Yang BH, Piao ZG, Kim YB, Lee CH, Lee JK, Park K, Kim JS, Oh SB. Activation of vanilloid receptor 1 (VR1) by eugenol. J Dent Res 2003; 82: 781-785.

[107] Yoshifumi I. Effects of eugenol on the central nervous system: Its possible application to treatment of Alzheimers disease, depression, and Parkinsons disease. Current Bioactive Compounds 2006; 2(1): 57 66. 
[108] Tung Y, Chua M, Wang S and Chang S, Anti-inflammation activities of essential oil and its constituents from indigenous cinnamon (Cinnamomum osmophloeum) twigs. Bioresource Technol 2008; 99: 39083913.

[109] Lee Y, Hung SL, Pai SF, Lee YH and Yang SF, Eugenol suppressed the expression of lipopolysaccharide-induced proinflammatory mediators in human macrophages $\mathbf{J}$ of Endodontics 2007; 33: 698-702.

[110] Laekeman G.M, van Hoof L, Haemers A, Berghe DAV, Herman AG and Vlietinck AJ. Eugenol a valuable compound for in vitro experimental research and worthwhile for further in vivo investigation. Phytother Res 1990; 4: 90-96.

[111] Ali SM, Khan AA, Ahmed I, Musaddiq M, Ahmed KS, Polasa H, Rao LV, Habibullah CM, Sechi LA and Ahmed N. Antimicrobial activities of eugenol and cinnamaldehyde against the human gastric pathogen Helicobacter pylori. Ann Clin Microbiol Antimicrob 2005; 4: 20-24.

[112] van Zyl RL, Seatlholo ST, van Vuuren SF and Viljoen AM. The biological activities of 20 nature identical essential oil constituents. J Essent Oil Res 2006; 18: 129-133.

[113] Leite AM, Lima EDO, de Souza EL, Diniz MDF, Trajano VN and de Medeiros IA. Inhibitory effect of $\beta$-pinene, $\alpha$-pinene and eugenol on the growth of potential infectious endocarditis causing Gram-positive bacteria. Braz J Pharm Sci 2007; 43: 121-126.

[114] El-Abed S, Houari A, Latrache H, Remmal A and Koraichi SI. In vitro activity of four common essential oil components against biofilm-producing Pseudomonas aeruginosa. Res J Microbiol 2011; 6: 394-401.

[115] He M, Du M, Fan M and Bian Z. In vitro activity of eugenol against Candida albicans biofilms. Mycopathologia 2007; 163: 137-143.

[116] Ramage G, Saville SP, Thomas DP and Lopez-Ribot JL. Candida biofilms: an update. Eukaryot Cell 2005; 4: 633- 638.

[117] Lopez-Ribot JL. Candida albicans biofilms: more than filamentation. Curr Biol 2005; 15: R453-R455.

[118] Hemaiswarya S and Doble M. Synergistic interaction of eugenol with antibiotics against Gram-negative bacteria. Phytomedicine 2009; 16: 997-1005.

[119] Moon SE, Kim HY and Cha JD. Synergistic effect between clove oil and its major compounds and antibiotics against oral bacteria. Arch Oral Biol 2011; 56: 907-916.

[120] Pei RS, Zhou F, Ji BP and Xu J. Evaluation of combined antibacterial effects of eugenol, cinnamaldehyde, thymol, and carvacrol against E. coli with an improved method. J Food Sci 2009; 74: M379-M383.

[121] Han QX and Huang SS. The effect of eugenol on biological activity of red flour beetle. Chong Qing Shi Fan Da Xue Xue Bao (Zi Ran Ke Xue Ban) 2009; 26(3):16-9.

[122] Li YM, Xiang SY, Zhu WJ, et al. Field experiment by using methyleugenol to trap and kill Dacus dorsalis (male). Nong Yao Ke Xue Yu Guan Li 2010; 31(6):49-50.

[123] Capasso R, Pinto L, Vuotto ML and Di Carlo G. Preventive effect of eugenol on PAF and ethanolinduced gastric mucosal damage. Fitoterapia 2000; 71: S131-S137.

[124] Morsy MA and Fouad AA. Mechanisms of gastroprotective effect of eugenol in indomethacin induced ulcer in rats. Phytother Res 2008; 22: 1361-1366.

[125] Bennett A, Stamford IF, Tavares IA, Jacobs S, Capasso F, Mascolo N and Autore G. The biological activity of eugenol, a major constituent of nutmeg [Myristica fragrans]: Studies on prostaglandins, the intestine and other tissues. Phytother Res 1988; 2: 124-130.

[126] Trailovic MS, Robertson PA and Jelena NT. Inhibitory effect of eugenol on rat ileal motility in vitro. Acta Vet 2009; 59: 123-131.

[127] Lima FC, Peixoto-Neves D, Gomes MD, Coelho-de-Souza AN, Lima CC. Araújo Zin W, Magalhães PJC, Saad L and Leal-Cardoso JH. Antispasmodic effects of eugenol on rat airway smooth muscle. Fundam Clin Pharm 2011; 25: 690-699.

[128] Yoo CB, Han KT, Cho KS, Ha J, Park HJ, Nam JH, KilUH and Lee KT. Eugenol isolated from the essential oil of Eugenia caryophyllata induces a reactive oxygen species-mediated apoptosis in HL-60 human promyelocytic leukemia cells. Cancer Lett 2005; 225: 41-52.

[129] Ghosh R, Nadiminty N, Fitzpatrick JE, Alworth WL, Slaga TJ and Kumar AP. Eugenol causes melanoma growth suppression through inhibition of E2F1 transcriptional activity. J Biol Chem 2005; 18: 5812-5829.

[130] Ghosh R, Ganapathy M, Alworth WL, Chan DC and Kumar AP. Combination of 2-methoxyestradiol (2ME2) and eugenol for apoptosis induction synergistically in androgen independent prostate cancer cells. J Steroid Biochem Mol Biol 2009; 113: 25-35.

[131] Hussain A, Brahmbhatt K, Priyani A, Ahmed M, Rizvi TA and Sharma C. Eugenol enhances the chemotherapeutic potential of gemcitabine and induces anticarcinogenic and anti-inflammatory activity in human cervical cancer cells. Cancer Biother Radiopharm 2011; 26: 519-527. 
[132] Jaganathan SK, Mazumdar A, Mondhe D and Mandal M. Apoptotic effect of eugenol in human colon cancer cell lines. Cell Biol Int 2011; 35: 607-615.

[133] Mahboub R and Memmou F. Antioxidant activity and kinetics studies of eugenol and 6-bromoeugenol. Nat Prod Res 2015; 29(10): 966-971.

[134] Lahlou S, Interaminense LF, Magalhães PJ, Leal-Cardoso JH and Duarte GP. Cardiovascular effects of eugenol, a phenolic compound present in many plant essential oils, in normotensive rats. J Cardiovasc Pharmacol 2004;43(2):250-257.

[135] Sánchez-Guerrero IM, Escudero AI, Bartolom B and Palacios R. Occupational allergy caused by carnation (Dianthus caryophyllus). J Allergy Clin Immunol 1999; 104(1): 181-185.

[136] Kong X, Liu X, Li J and Yang Y. Advances in pharmacological research of eugenol. Curr Opin Complement Alternat Med 2014; 1(1): 8-11. 